ACTA MYCOLOGICA

Vol. 41 (1): 145-154

2006
It is a great pleasure and honour to dedicate this paper to Professor Alina Skirgiełło, who always cared for Lithuania and its mycology

\title{
Lichens of neglected habitats in Eastern and East-Central European lowlands
}

\author{
JURGA MOTIEJŪNAITE் \\ Laboratory of Mycology, Institute of Botany, Žaliųjų ežerų str. 49, \\ LT 08406 Vilnius 21, mikojm@botanika.lt
}

Motiejūnaitè J.: Lichens of neglected habitats in Eastern and East Central European lowlands. Acta Mycol. 41 (1): 145 154, 2006.

Situation of lichens of aquatic and transient habitats in Eastern and East-Central European lowlands is discussed basing on example of several selected species: Leptogium biatorinum, Sarcosagium campestre, Steinia geophana, Verrucaria aquatilis, V. hydrela, V. praetermissa, V.xyloxena. Both habitat types are generally very much neglected in the region and all species show large spatial gaps in recording, which makes it difficult to judge both about their true distribution limits and spreading dynamics. On the other hand, targeted search through the suitable habitats and abundance of such indicate that many of these lichens are probably not uncommon in the region.

Key words: Lichens, biogeography, aquatic habitats, transient habitats

\section{INTRODUCTION}

Rare lichens often make significant parts of national floras and provide the basis for red lists. However, "rare" might comprise both declining species and stable or spreading ones. Declining species are usually well known, more or less historically documented and confined to the habitats and substrates that are traditionally investigated by lichenologists. Meanwhile situation of many species defined as "rare" in national floras often remain obscure. Especially this is true for Eastern and EastCentral (EEC) Europe. The reasons for some lichen to be defined as rare can be several:

1. The species are "new" - relatively recently described.

2. The species are taxonomically "difficult", they are often reported as complexes or not separated from similar species.

3. The species are connected to particular habitats or niches that are neglected by lichenologists. 
"New", recently described species comprise lichens, which have been described during the last two decades. Presence of such species in the national lists generally indicates degree of recent lichenological activity (see e.g. Motiejūnaité 2005). Taxonomically „difficult" species are either scarce or totally excluded from the floras or inventory lists of eastern Europe (e.g., most of sterile crustose lichens) or poorly distinguished, e.g. see notes for Acrocordia cavata in Motiejū naitè (2005) or Anisomeridium polypori in Czyżewska et al. (2005). Species associated with habitats neglected by lichenologists make a weird group, indicating, to certain extent, activities of lichenologists, the variability of fieldwork and nature of lichenological coverage. Species of this group are often mentioned in discussions about lichen flora dynamics, as most of them are considered to be rare in many European countries; a sudden boost in locality numbers after specific habitat studies might result in a discussion as to whether the species is spreading or not, whether the species is a neophyte or a long-present member of the national flora.

Typical examples of neglected habitats are lowland freshwater bodies and transient habitats, both of which receive only sporadic attention from lichenologists. The purpose of this paper was to review situation of lichens associated with both these habitats in EEC Europe and to attract attention to the importance of study of these habitats. For the aims of the paper several species should be characteristic to aquatic and transient habitats were selected. Their known distribution and situation in EEC Europe were analysed mainly on the basis of all available literature sources and to some extent of herbarium collections (mainly Lithuanian).

\section{TERRITORY UNDER DISCUSSION}

For the review temperate and cool temperate forest zone of lowland EEC Europe (between ca. $20^{\circ}$ and $55^{\circ}$ longitude and $53^{\circ}$ and $63^{\circ}$ latitude) was chosen. Though the area is biogeographically complex, it still holds certain homogeneity pertaining conditions for lichen distribution. There are no large natural obstacles for lichen dispersal in this area, the only limiting factors for their spread being climatic and edaphic. Though land-use history and intensity vary from country to country, there are still many similarities connected with long periods of similar administrative history. Many traditional rural activities persist, such as use of local building materials resulting in sand-, gravel- and loam-pits, and of untreated timber for buildings (although the latter tendency is decreasing lately at least in part of the territory).

Administratively the territory includes Polish lowlands (P), Baltic countries - Lithuania (Li), Latvia (La), Estonia (E), Belarus, and the forest zones of the Ukrainian lowlands (U) and of European Russia (R).

\section{RESULTS AND DISCUSSION}

Lichens of aquatic habitats. Aquatic habitats, though locally well studied in Western and Central Europe (see e.g. Gilbert 1996; Gilbert, Giavarini 1997; Molitor, Diederich 1997; Keller 2000; Thüs 2002) are very much under-recorded in EEC Europe, especially in its lowland parts. Both numbers of recorded species are low and the records themselves are sparse, though when well studied, aquatic environs show to be rich in lichens. Crustose lichens are espe- 
cially understudied, among which perithecioid species prevail. Verrucaria aquatilis, $V$. hydrela and $V$. praetermissa are the most common freshwater aquatic perithecioid lichens in the region, their distribution and status reflects situation of whole group.

Distribution of these lichens in EEC Europe reflects solely regional activity of lichenologists and gives no clear pattern of geographical ranges. Most of them (except $V$. hydrela) are attributed to suboceanic species, occurring mainly in temperate zone. Generally, these lichens are quite well known in Western and Central Europe, but are very much under-recorded in the east. Aquatic Verrucaria species are found almost exclusively in southeastern and eastern region of the Baltic sea (Figs. 1-3). Though there is no shortage of suitable habitats in Eastern Europe, aquatic lichens, especially crustose species are almost utterly omitted from lichen inventories. Judging by the known distribution and tendencies of recording, aquatic Verrucaria species should be found also further eastwards in pristine streams of forested areas, as it is demonstrated by a record of $V$. hydrela outside of the discussed area, in southern part of the Baikal lake region (Urbanavichene, Urbanavichus 1999). Besides, these lichens are source of taxonomic confusion, which is discernible even among scarse records (e.g., the record of V. praetermissa in Kaliningrad region, Russia (Andreev 2002) suggests V. elaeina (see Orange 2000).

Frequencies of these lichens in the discussed region are as hypothethical, as their distribution ranges. In most cases they range from very rare to rather rare in all countries (Tab. 1), though it is admitted that overlooking is the main reason for the record scarcity (e.g. for Verrucaria hydrela in Northern Poland (Jando, Kukwa 2003).

Dynamics of these species as well as conservational value are even less clear. Generally, aquatic lichens are connected with vulnerable habitats, as most of them inhabit pristine streams, little influenced by eutrophication (see Gilbert 1996; Gil bert, Giavarini 1997; Thüs 2002; Motiejūnaite 2003). This is well expressed by the fact that aquatic Verrucaria species are red-listed in West-European areas of intensive urban and agricultural land use: V. aquatilis and V. hydrela - in Denmark (Søchting 1997) and lowland lands in Germany (variable categories, Wirth et al. 1996); V. praetermissa - in German lowland lands (Critically endangered to Rare). Thus, they could be attributed to habitat-demanding and decreasing species. In EEC Europe, aquatic Verrucaria species are red-listed only in Poland (Tab. 1).

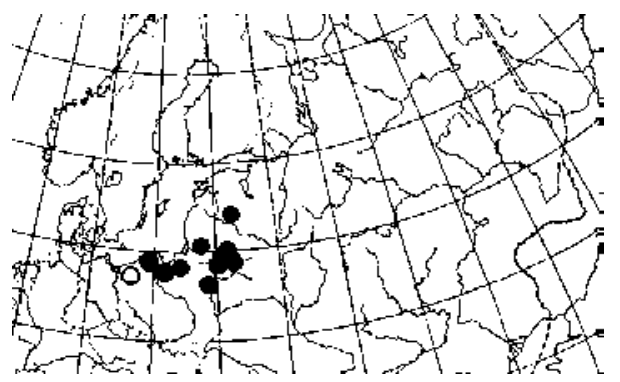

Fig. 1. Distribution of Verrucaria aquatilis in Eastern and East Central Europe

records more than 50 year old,

- modern records

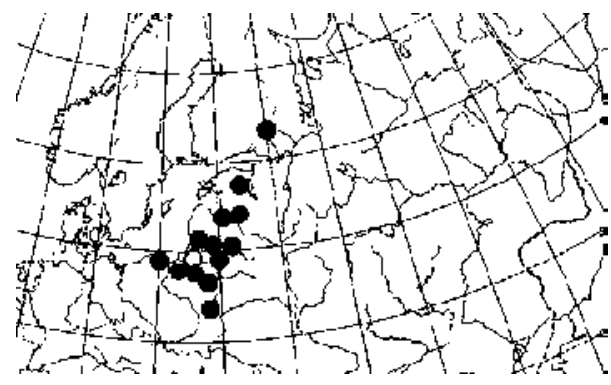

Fig. 2. Distribution of Verrucaria hydrela in Eastern and East Central Europe

records more than 50 year old,

- modern records 


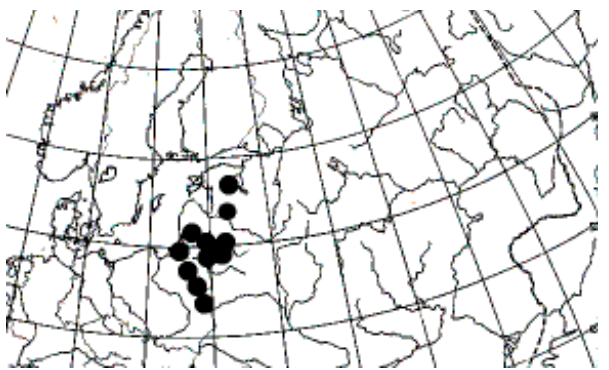

Fig. 3. Distribution of Verrucaria praetermissa in Eastern and East Central Europe modern records

Lichens of transient habitats. Lichens of transient habitats are ephemeral, generally inconspicuous and rarely recorded, therefore are presumed to be nationally rare in almost all European countries. Most often such habitats are man-made, like bare soil of roadside scarps, edges of dirtroads, gravel-, sand- or loam-pits. Such places bear diverse albeit very much understudied lichen flora (see e.g. Ernst 1993, 1995). Leptogium biatorinum, Sarcosagium campestre, Steinia geophana and Verrucaria xyloxena represent typical members of pioneer lichen communities inhabiting transient man-made habitats in EEC European lowlands. All these species are probably widely distributed both regarding climatic zones and oceanic gradient.

Distribution of these lichens in EEC Europe even more strongly reflects regional activity of lichenologists, as these species are most often recorded during targeted studies of specific habitats. To date, the widest distribution in west-east direction is demonstrated by Sarcosagium campestre (Fig. 4), Verrucaria xyloxena (Fig. 5), and Leptogium biatorinum (Fig. 6), two latter species being recorded also outside the discussed region of EEC Europe, in the steppe zone in Russia (Ve dene ev 1999; Muchnik 2001; Shustov 2002). Steinia geophana is more widely distributed in a south-north direction (Fig. 7): outside the discussed area its range reaches Kola Peninsula in Russia (BILAS herbarium, specimens No. 5304 and 5339). However, not all of this data is totally reliable, as at least two species can be source of taxonomic confusion. In some references (Western European as well) L. biatorinum is not differentiated from $L$. byssinum (Jørgensen 1994). In earlier Russian and Ukrainian references (Oksner 1956; Inashvili 1975), the description of $L$. byssinum

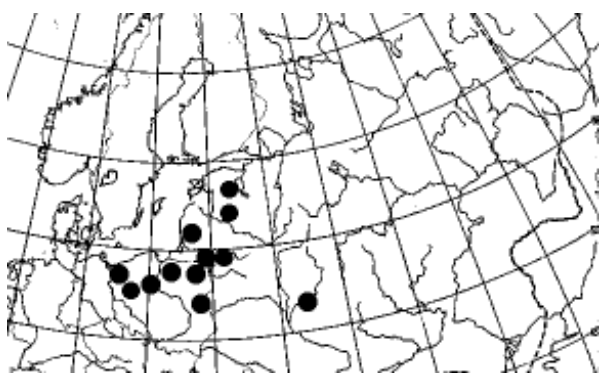

Fig. 4. Distribution of Sarcosagium campestre in Eastern and East Central Europe

- modern records

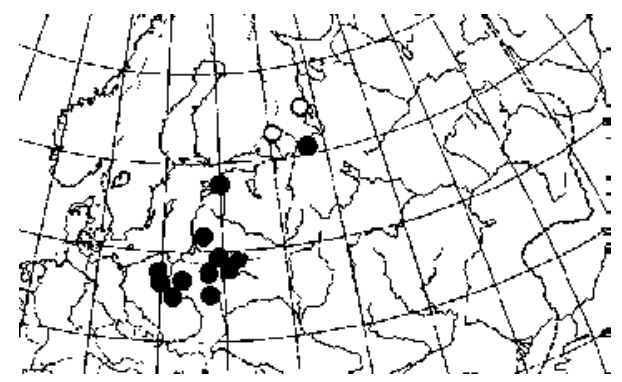

Fig. 5. Distribution of Verrucaria xyloxena in Eastern and East Central Europe

O records more than 50 year old,

- modern records 
Table 1

Distribution, frequency and conservation status of the selected lichen species in Eastern and East Central European lowlands

Frequency abbreviations: vr (very rare), $\mathrm{r}$ (rare), rr (rather rare), rf (rather frequent), $\mathrm{f}$ (frequent), vf (very frequent). Frequency evaluations for Lithuania are given according to Motiejūnaitè (2002a), for Estonia according to Randlane and Saag (1999), for Latvia according to Piterāns (2002) (in part). In some cases parts of countries are indicated (e.g., NE north eastern, $\mathrm{C}$ central). Conservation status abbreviations: VU (Vulnerable), NT (Near threatened), DD (Data deficient). References for conservation information: Cieśliński (2003b), Cieśliński et al. (2003). For country abbreviations see chapter "Territory under discussion".

\begin{tabular}{|c|c|c|c|}
\hline Species & $\begin{array}{l}\text { Countries, } \\
\text { frequency }\end{array}$ & References & $\begin{array}{c}\text { Conservation } \\
\text { status }\end{array}$ \\
\hline $\begin{array}{l}\text { Leptogium } \\
\text { biatorinum (Nyl.) } \\
\text { Leight. }\end{array}$ & $\begin{array}{l}\mathrm{P}(\mathrm{rr}), \mathrm{Li}(\mathrm{rr}), \mathrm{Lv} \\
(\mathrm{vr}), \mathrm{R}(\mathrm{vr})\end{array}$ & $\begin{array}{l}\text { Lettau 1912; Ceynowa Giełdon } \\
\text { 2001; Cieśliński 2003a; Motiejūnaite } \\
\text { et al. } 2006\end{array}$ & \\
\hline $\begin{array}{l}\text { Sarcosagium } \\
\text { campestre (Fr.) } \\
\text { Poetsch \& Schied. }\end{array}$ & $\begin{array}{l}\mathrm{P}(\mathrm{rr}), \mathrm{Li}(\mathrm{rr}), \mathrm{Lv} \\
(\mathrm{vr}), \mathrm{U}(\mathrm{vr}), \mathrm{E}(\mathrm{vr})\end{array}$ & $\begin{array}{l}\text { Lipnicki 1991; Fałtynowicz } \\
\text { 1992, 2003; Kondratyuk et al. } \\
\text { 1998; Ceynowa Giełdon 1999; } \\
\text { Rutkowski, Słowik 1999; Cieśliński } \\
\text { 2003a; Sparrius 2003; Suija et al. 2005; } \\
\text { Motiejūnaitè et al. 2006; Kukwa, } \\
\text { pers. com. }\end{array}$ & \\
\hline $\begin{array}{l}\text { Steinia geophana } \\
\text { (Nyl.) Stein }\end{array}$ & $\begin{array}{l}\mathrm{P}(\mathrm{r}), \mathrm{Li}(\mathrm{rr}), \mathrm{E}(\mathrm{r}), \\
\mathrm{R}(\mathrm{vr})\end{array}$ & $\begin{array}{l}\text { Fałtynowicz 1993; 2003; Fadeeva et } \\
\text { al. 1997; Ceynowa Giełdon 1998, } \\
\text { 1999; Zavarzin et al. 1999; Halonen et } \\
\text { al. 2000; Kuznetsova, Himelbrant } \\
\text { 2002; Cieśliński 2003a; Aptroot et } \\
\text { al. 2005 }\end{array}$ & $\mathrm{P}(\mathrm{NT}$ in $\mathrm{NE})$ \\
\hline $\begin{array}{l}\text { Verrucaria aquatilis } \\
\text { Mudd }\end{array}$ & $\begin{array}{l}\text { P (vr), Li (rr), La } \\
\text { (vr), R (vr) }\end{array}$ & $\begin{array}{l}\text { Kopachevskaya 1977; Fałtynowicz } \\
\text { 1992; Rutkowski 1993; Fade eva et } \\
\text { al. 1997; Fałtynowicz et al. 2000; } \\
\text { Kowalewska et al. 2000; Kukwa 2000; } \\
\text { Cieśliński 2003a; Motiejūnaite et } \\
\text { al. } 2006\end{array}$ & $\begin{array}{l}\mathrm{P}(\mathrm{VU}, \mathrm{DD} \text { in } \\
\mathrm{NE})\end{array}$ \\
\hline $\begin{array}{l}\text { Verrucaria hydrela } \\
\text { Ach. }\end{array}$ & $\begin{array}{l}\text { P (rr), Li (f), La } \\
(r), E(v r), \text { R (vr) }\end{array}$ & $\begin{array}{l}\text { Lettau 1912; Piterāns 1982; Fadeeva } \\
\text { et al. } 1997 ; \text { Fałtynowicz et al. 2000; } \\
\text { Halonen et al. 2000; Kowalewska et } \\
\text { al. 2000; Kukwa 2000; Fałtynowicz, } \\
\text { Królak 2001; Ciésiński } 2003 a ; \\
\text { Jando, Kukwa 2003; Motiejūnaitè } \\
\text { et al. 2006 }\end{array}$ & $\begin{array}{l}\mathrm{P}(\mathrm{VU}, \text { not red } \\
\text { listed in NE) }\end{array}$ \\
\hline $\begin{array}{l}\text { Verrucaria } \\
\text { praetermissa } \\
\text { (Trevis.) Anzi }\end{array}$ & $\begin{array}{l}\text { P (vr), Li (rf), La } \\
\text { (vr), E (vr), R (vr) }\end{array}$ & $\begin{array}{l}\text { Halonen et al. 2000; Andreev 2002; } \\
\text { Cieśliński 2003a; Motiejūnaité et } \\
\text { al. } 2006\end{array}$ & $\begin{array}{l}\mathrm{P}(\mathrm{NT}, \mathrm{DD} \text { in } \\
\mathrm{NE})\end{array}$ \\
\hline $\begin{array}{l}\text { Verrucaria xyloxena } \\
\text { Norman }\end{array}$ & $\begin{array}{l}\text { P (rf, common in } \\
\text { C), Li (rr), E (vr), } \\
\text { R (vr) }\end{array}$ & $\begin{array}{l}\text { Orange 1991; Ceynowa Giełdon } \\
\text { 1998; Randlane, Saag 1999; } \\
\text { Cieśliński 2003a; Kuznetsova, pers. } \\
\text { com. }\end{array}$ & \\
\hline
\end{tabular}




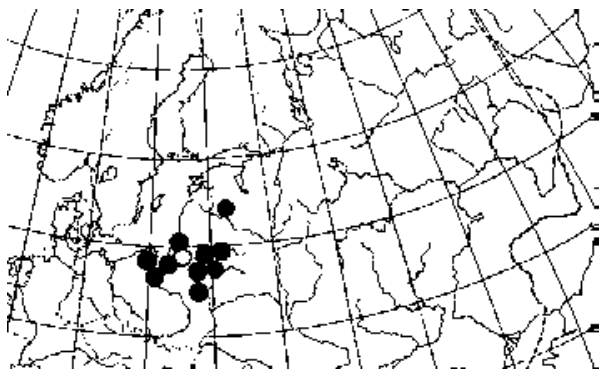

Fig. 6. Distribution of Leptogium biatorinum in Eastern and East Central Europe

O records more than 50 year old,

- modern records

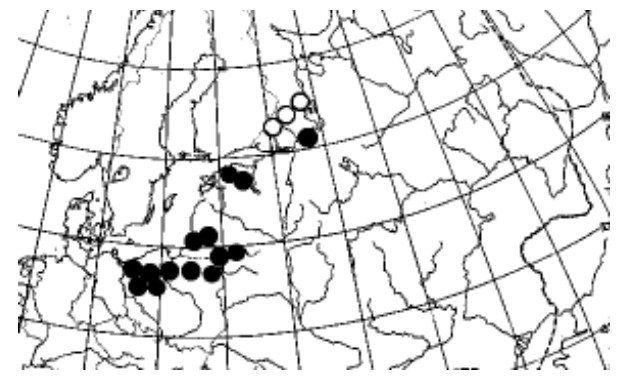

Fig. 7. Distribution of Steinia geophana in Eastern and East Central Europe

O records more than 50 year old,

- modern records

can accomodate both species. In Estonia only L. byssinum is recorded (Randlane, Saag 1999) basing only on literature data, thus the identity of the species is questionable. Illustrations and descriptions in Polish references (Now ak, Tobolewski 1975; Cey now - Giełd on 1999) define both lichens very well. Le t ta u (1912) also circumscribed these two species. Part of the reports of $V$. xyloxena southeastwards of the discussed area (Voronezh, Volgograd, Samara, Saratov, Uljanovsk regions of Russia) might be doubtful - the species is reported as saxicolous (Muchnik 2001; Shustov 2002).

Frequencies of transient habitat species in Eastern Europe reflect general recording - locally they are reported as quite common, but data is totally absent from most of the territory. In most countries they are reported to be rare or very rare (Tab. 1). Regardless record scarcity, it can be assumed that they are much more frequent, as traditionally there are numerous habitats suitable for these lichens, such as sand-, gravel- and loam-pits which are present in almost every village, dirtroads, road scarps, etc. and recording does not show any tendencies of decrease. Even a cursory search through such habitats can result in a variety of finds (e.g. Motiejūnaitè 2002b; Sparrius 2003), and intensive targeted search can totally change frequency patterns (Ceyn owa-Giełd on 1998, 1999, 2001). There are different opinions concerning the dynamics of these species in Europe. In Jørgensen (1994) and Jørgensen and Motiejūnaitè (2005) species of transitional habitats are presumed to be decreasing due to modern agricultural methods. Woods and Coppins (2003) express opinion that species of transient habitats should be excluded from the red-lists, though they evaluate Verrucaria xyloxena as Critically Endangered in the same reference. However, in some countries lichens of transient habitats are given threat status: Leptogium biatorinum is red listed in Denmark, Finland (Vitikainen et al. 1997) and in lowland lands of Germany (categories range from Extinct to Poorly known); Sarcosagium campestre and Steinia geophana - in Denmark and in lowland lands of Germany (variable categories); Verrucaria xyloxena is red-listed in Germany as Data deficient (not recorded in lowland lands). In EEC Europe, lichens of transient habitats can hardly be qualified as threatened though Steinia geophana is red listed in NE Poland. On the contrary, part of these lichens might belong to spreading species, as they occupy niches that are naturally scarce in the discussed region and appear mainly in connection with human activities. 


\section{CONCLUSIONS}

As the examples in this paper have shown, there are large spatial gaps in recording lichens of aquatic and transitional habitats in EEC Europe, making these lichens nationally rare in almost all countries in the discussed region. Also there exists certain degree of taxonomic confusion pertaining these species.

Lichen floras, resulting from species inventories make base for environmental evaluation and monitoring programmes, land manegement policy making, etc. Disregard of certain habitats or species, or on the contrary, detailed study of all habitat types and all species present might lead to very different results of lichen inventories (see e.g. Lõ hmus et al. 2003) and subsequently, to erroneous interpretations of monitoring evaluation results. In wider scale, both historical and present understudy of some habitats leads to the dearth of knowledge on true lichen distribution areas and tendencies of their decrease or spreading and often disable biodiversity monitoring projects in larger geographical scale.

Acknowledgements: I would like to express my sincere thanks to my colleagues prof. K. Czyżewska (Łódż), dr. M. Kukwa (Gdańsk), dr. V. Golubkov (Grodno), Mr. D. Himelbrant and Ms. E. Kuznetsova (St. Peterburg) for the data they supplied and allowed to use in the paper and their valuable comments on the manuscript.

\section{REFERENCES}

Andreev M.P. 2002. Dopolnenije k likhenoflore Kaliningradskoi oblasti Rossii: lishainiki kamen istykh substratov. Novosti Sist. Nizsh. Rast. 36: 6872.

Aptroot A., Czarnota P., Jüriado I., Kocourková J., Kukwa M., Lõhmus P., Palice Z., Randlane T., Saag L., Sérusiaux E., Sipman H., Sparrius L. B., Suija A., Thüs H. 2005. New or interesting lichens and lichenicolous fungi found during the 5th IAL Symposium in Estonia. Folia Cryptog. Estonica 41: 1322.

Ceynowa Giełdon M. 1998. Naziemne gatunki porostów z rodzaju Verrucaria (Lichenes, Verru cariaceae) na Kujawach i niektórych terenach sąsiednich. Fragm. Flor. Geobot. Ser. Polonica 5: 243249.

Ceynowa Giełdon M. 1999. Leptogium byssinum (Lichenes, Collemataceae) na Kujawach i tere nach sąsiednich nad dolną Wislą. Fragm. Flor. Geobot. Ser. Polonica 6: 227234.

Ceynowa Giełd on M.2001. Kalcyfilne porosty naziemne na Kujawach. Wyd. Uniwersytetu Mikołaja Kopernika, Toruń, 44 pp.

Cieśliński S. 2003a. Atlas rozmieszczenia porostów (Lichenes) w Polsce Północno Wschodniej. Phy tocoenosis 15 (N.S.), Suppl. Cartogr. Geobot. 15: 1430.

Cieśliński S. 2003b. Czerwona lista porostów zagrożonych w Polsce Północno Wschodniej. Monogr. Bot. 91: 91106.

Cieśliński S., Czyżewska K., Fabiszewski, J. 2003. Czerwona lista porostów wymarłych i zagrożonych w Polsce. Monogr. Bot. 91: 1349.

Czyżewska K., Motiejūnaitė J., Cieśliński S. 2005. New and noteworthy species of lichens and allied fungi from North Eastern Poland. Acta Mycol. 40 (2): 277291.

Ernst G. 1993. Zur Ökologie und Verbreitung von Geisleria sychnogoniodes, einer bislang kaum bekan nten terricolen Flechte. Herzogia 9: 321337.

Ernst G. 1995. Vezdaea leprosa Spezialist am Straßenrand. Herzogia 11: 175188.

Fadeeva M.A., Golubkova N.S., Vitikainen O., Ahti T. 1997. Predvaritel'nyj spisok lishajnikov Karelii i obitajushchikh na nikh gribov. Karel'skij nauchnyj centr RAN. Petrozavodsk.

Fałtynowicz W. 1992. The lichens of Western Pomerania (NW Poland). An ecogeographical study. Polish Bot. Stud. 4: 1182. 
Fałtynowicz W. 1993. Steinia geophana (Nyl.) B. Stein. (In:) S. Cieśliński, W. Fałtynowicz (eds.), Atlas of the geographical distribution of lichens in Poland. Part 1. W. Szafer Institute of Botany, Polish Academy of Sciences, Kraków, p. 6567.

Fałtynowicz W. 2003. The lichens, lichenicolous and allied fungi of Poland. An annotated checklist. Biodiversity of Poland 6. W. Szafer Institute of Botany, Polish Academy of Sciences, Kraków, 435 pp..

Fałtynowicz W., Marcinkowska E., Rutkowski P. 2000. Porosty rezerwatu „Dolina Zagór skiej Strugi” koło Rumii na Pojezierzu Kaszubskim. Acta Bot. Cassubica 1: 119126.

Fałtynowicz W., Królak D. 2001: Porosty rezerwatu „Jar Rzeki Raduni” na Pojezierzu Kaszub skim (pólnocna Polska). Acta Bot. Cassubica 2: 133141.

Gilbert O.L. 1996. The lichen vegetation of chalk and limestone streams in Britain. Lichenologist 28: 145159.

Gilbert O.L., Giavarini V.J. 1997. The lichen vegetation of acid watercourses in England. Li chenologist 29: 347367.

Halonen P., Kukwa M., Motiejunaite J., Lõhmus P., Martin, L. 2000. Notes on lichens and lichenicolous fungi found during the XIV Symposium of Baltic Mycologists and Lichenologists in Järvselja, Estonia. Folia Cryptog. Estonica 36: 1721.

Inashvilli C.N.1975. Sem. Collemataceae. (In:) O. B. Blum, A. V.Dombrovskaya, C N.Inashvilli, A. V.Piterāns, E. G. Roms, V. P. Savicz (eds), Opredeltel lishainikov SSSR. 3. Caliciaceae Gyalectaceae. Nauka, Leningrad: 80118.

Jand o K., Kukwa M. 2003. Porosty, grzyby naporostowe i nażywiczne projektowanego rezerwatu „Wiszące Torfowiska nad jeziorem Jaczno” oraz terenów przyleglych do jeziora Jaczno w Suwalskim Parku Krajobrazowym (Północno Wschodnia Polska). Parki nar. Rez. przyr. 22 (1): 317.

J $\emptyset$ rgensen P. M. 1994. Further notes on European taxa of the lichen genus Leptogium, with emphasis on the small species. Lichenologist 26: 129.

Jørgensen P. M., Motiejūnaitè J. 2005. Lemmopsis pelodes (Körb. ex Stein) Ellis found in Lithu ania. Graphis Scripta 17 (1): 1719.

Kelle r C. 2000. Die Wasserflechten der Teigtisch zwischen der Landmannsperre und dem kraftwerk Arnsein (Steiermark, Österreich). Herzogia 14: 4958.

Kondratyuk S.Ya, Khodosovtsev A.Ye., Zelenko S.D. 1998. The second checklist of lichen forming, lichenicolous and allied fungi of Ukraine. Phytosociocentre, Kiev.

Kopachevskaya E.G. 1977. Sem. Verrucariaceae. In: Kopachevskaya E.G., Makarevich M.F., Oksner, A.N. Opredelitel` lishainikov SSSR. 4. Verrucariaceae Pilocarpaceae: 754. Nauka, Leningrad.

Kowalewska A., Jando K., Kukwa M. 2000. Lichens and lichenicolous fungi of the protected nature reserve "Przyjaźn", protecting the forest support surrounded by the cultivated fields (Kaszu by lakes district, N. Poland). (In:) Pervaja Rosijskaya Likhenologicheskaya shkola i mezhdunarodnyj simpozium molodykh likenologov "Arktoalpijskaja flora. Okhrana lishainikov". Programma i tezisy dokladov. Apatity: 75 .

Kukwa M. 2000: Porosty i grzyby naporostowe zachodniej cześci Pojezierza Ilawskiego (Polska pól nocna). Fragm. Flor. Geobot. Ser. Polonica 7: 281297.

Kuznetsova E.S., Himelbrant D. E. 2002. Dopolnenye k flore lishainikov Nizhesvirskogo zapo vednika. Novosti Sist. Nizhsh. Rast. 36: 144150.

Lettau G. 1912. Beiträge zur Lichenenflora von Ost und Westpreussen. Festschrift zum 50 jährigen bestehen des preussischen botanischen vereins Königsberg 53:17 91.

Lipnicki L. (ed.). 1991. Porosty (Lichenes) Pszczewskiego Parku Krajobrazowego. (In:) V Meeting of Polish lichenologists: 5 32. Inst. Bad. Ekspertyzy Nauk., Gorzów Wlkp.

Lõ hmus P., Saag L., Lõhmus A. 2003. Is there merit in identifying leprarioid crusts to species in ecological studies? Lichenologist 35: 187190.

Molitor F., Diederich P. 1997. Les pyrénolichens aquatiques du Luxembourg et leurs champig nons lichénicoles. Bull. Soc. Nat. luxemb. 98: 6992.

Motiejūnaitè J. 2002a. Lapiškosios ir krūmiškosios kerpès (Ascomycetes lichenisati. Species foli osae et fruticosae). Lietuvos grybai 13(1). Valstiečių laikraštis, Vilnius.

Motiejūnaitè J. 2002b. Diversity of lichens and lichenicolous fungi in the transboundary region of Marijampole district (southern Lithuania). Botanica Lithuanica 8: 277294. 
Motiejūnaitè J. 2003. Aquatic lichens in Lithuania. Lichens on submerged alder roots. Herzogia 16: 113121.

Motiejūnaitè J. 2005. Distribution of some rare and declining lichen species in lowland eastern and eastern central Europe. Biologia (Bratislava) 60 (4): 357363

Motiejūnaitè J., Piterāns A., Suija A., Lõhmus P., Kuznetsova E., Tõrra T., Pri godina Lukošienè I. 2006. New or noteworthy lichens, lichenicolous and allied fungi found during the 16th Symposium of Mycologists and Lichenologists in Latvia. Botanica Lithuanica (in prep.).

Muchnik E.E. 2001. Konspekt lishainikov stepnykh i ostepnennykh mestoobitanij central'nogo Cher nozemja. Novosti Sist. Nizhsh. Rast. 35: 183195.

Nowak J., Tobolewski Z. 1975. Porosty polskie. Państwowe Wydawnictwo Naukowe, Warszawa Kraków.

Orange A. 1991. Notes on some terricolous species of Verrucaria. Lichenologist 23: 310.

Orange A. 2000. Verrucaria elaeina, a misunderstood European lichen. Lichenologist 32: 411422

Oksne r A.M. 1956. Flora lishainikiv Ukraini. Tom I. Akademiya Nauk Ukrainskoi RSR, Institut Bo taniki, Kiev.

Piterāns A. V. 1982. Lishainiki Latvii. Zinatne, Riga.

Piterāns A. 2002. Lichens of Latvia. http://latvijas.daba.lv/scripts/db/saraksti/saraksti. cgi?d=keerpji\&l=en. [Last modified: 20.05.2002].

Randlane T., Saag A. (eds) 1999. Second checklist of lichenized, lichenicolous and allied fungi of Estonia. Folia Cryptog. Estonica 35: 1132.

Rutkowski P. 1993. Flora i ekologia porostów rezerwatu „Jar Rzeki Reknicy” na Pojezierzu Kaszub skim. Parki nar. Rez. przyr. 12 (4): 2940.

Rutkowski P., Słowik J. 1999. Flora porostów doliny Drwęcy w okolicach Nowego Miasta Lubaws kiego. Fragm. Flor. Geobot. Ser. Polonica 6: 211217.

Shustov M. V. 2002. Lishainiki Privolzhskoi vozvyshennosti. Novosti Sist. Nizsh. Rast. 36: 185203.

Søchting U. 1997. Laver. [In:] Rødliste 1997 over planter og dyr i Danmark. http://www.sns.dk/net pub/rodliste/72.htm

Sparrius L.B. 2003. Contribution to the lichen floras of the Białowieża Forest and the Biebrza Valley (Eastern Poland). Herzogia 16: 155160.

Suija A., Nom m M., B och S. 2005. New Estonian records. Lichens and lichenicolous fungi. Folia Cryptog. Estonica 41: 135136.

Thüs H. 2002. Taxonomie, Verbreitung und Ökologie silicicoler Süßwasserflechten im außeralpinen Mitteleuropa. Bibl. Lichenol. 83: 1214.

Urbanavichene I.N., Urbanavichus G.P. 1999. K flore lishainikov khrebta Chamar Daban (Juzhnoje pribaikalje). Novosti Sist. Nizhsh. Rast. 33: 161171.

Vedeneev A.M. 1999. Lishainiki Sarepty (Volgogradskaja oblastj). Bot. Zhurn. 84 (11): 100107.

Vitikainen O., Ahti T., Kuusinen M., Lommi S., Ulvinen T. 1997. Checklist of lichens and allied fungi of Finland. Norrlinia 6: 1123.

Wirth V., Schöller H., Scholtz P., Ernst G., Feuerer T., Gnüchtel A., Hauck M., Jacobsen P., John V., Litterski B. 1996. Rote Liste der Flechten (Lichenes) der Bundesrepublik Deutschland. Schriftenreihe für Vegetationskunde 28: 307368.

Woods R.G., Coppins B.J. 2003. A Conservation Evaluation of British Lichens. British Lichen Society. London.

Zavarzin A.A., Katenina O.A., Kotlov Yu.V., Sokolova S.V. 1999. Lichens of St. Pe tersburg and Leningrad region. (In:) N.B.Balashova, A. A. Zavarzin (eds.), Biodiversity of the Leningrad region (Algae. Fungi. Lichens. Bryophytes. Invertebrates. Fishes and Pisciformes): 205 260. St. Petersburg University Press, St. Petersburg. 
Porosty słabo poznanych siedlisk na niżu Europy Środkowo-Wschodniej i Wschodniej

\section{Streszczenie}

W pracy przedstawiono rozmieszczenie, frekwencję i stopień zbadania porostów sie dlisk wodnych i krótkotrwałych w obrębie strefy leśnej niżu Europy Środkowo Wschodniej i Wschodniej: Polski, Litwy, Łotwy, Estonii i Białorusi oraz Ukrainy i europejskiej części Rosji. Oba typy siedlisk są bardzo słabo rozpoznane w tej części Europy. Zagadnienie to omówio no na przykładzie wybranych gatunków efemerycznych: Leptogium biatorinum, Sarcosagium campestre, Steinia geophana i Verrucaria xyloxena oraz wodnych: Verrucaria aquatilis, V. hydrela i $V$. praetermissa.

W skali wielkoprzestrzennej widoczne są luki w rozmieszczeniu badanych gatunków (Figs 17 ). Ustalenie ich rzeczywistego rozmieszczenia i dynamiki rozprzestrzenienia jest, jak na razie, trudne. Celowe poszukiwanie odpowiednich siedlisk i charakterystycznych im gatunków sygnalizuje, że mogą one być nawet częste w regionie. 